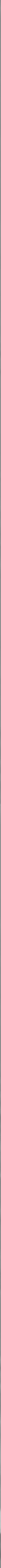

$\mathrm{Cr}_{\mathrm{r}} \mathrm{m}$

Pilinil $=2=$ $\mathrm{b}^{2} \times 4$ 


\title{
Ikoniczność i ucieczka od referencji (na przykładzie filmów Zbigniewa Rybczyńskiego) ${ }^{*}$
}

\begin{abstract}
Wysłouch Seweryna, Ikoniczność i ucieczka od referencji (na przykładzie filmów Zbigniewa Rybczyńskiego) [Iconicity and escape from reference]. "Przestrzenie Teorii" 11. Poznań 2009, Adam Mickiewicz University Press, pp. 9-23. ISBN 978-83-232-1986-6. ISSN 1644-6763.
\end{abstract}

The concept of reference comprises three different ways of expressing reality: simulation, representation and transformation, and it is just from this point of view that I analyse Rybczynski's films from the years 1976-1990.

Rybczyński was always against registration of reality and wants to present on the screen "mental pictures", i.e. that which exists in our thoughts, fantasies and dreams. He submits reality to grotesque deformation (Święto [Holiday], 1976), destroys iconicity of the text through playful metaphor (Lokomotywa (Locomotive) based on I. Tuwim's poem, 1976), creates on the screen surreal situations (Tango, 1980) and shows transformation of people and things (The Fourth Dimension, 1998). However, "mental pictures" also contain conventional cultural symbols, which are distinctly shown in Orchestra (1990). Therefore, lifting references leads into the world of signs and signs refer to the social experience, history and European culture. Through signs we reverse to the representation of reality.

Ikoniczność do niedawna traktowana była po macoszemu. Zdawałoby się, zakłada proste naśladowanie „widzialnej” rzeczywistości i ma ograniczone walory poznawcze. Ale już badania Ernsta H. Gombricha i Umberta Eco pokazywały duży udział konwencji w przedstawieniach ikonicznych, które mogą być nieczytelne dla istot obcych kulturowo (jak ów sławny list obrazkowy wysłany w latach 60 . w kosmos, mający poinformować jego ewentualnych mieszkańców o istnieniu naszej planety, jej miejscu we Wszechświecie i wyglądzie człowieka1). Eco rozróżniał dwa stadia w tworzeniu znaków ikonicznych: proces percepcji, związany z fizjologią wzroku i proces abstrakcji, który prowadzi do ukształtowania znaczenia, „modelu semantycznego”, a ten z kolei może ulegać dalszym

"Artykuł jest rozszerzoną wersją referatu wygloszonego na XXXVI Konferencji Teoretycznołiterackiej Kulturowe wizualizacje doświadczenia, zorganizowanej przez Zakład Poetyki Historycznej i Sztuki Przekładu Uniwersytetu Śląskiego w Katowicach oraz Pracownię Poetyki Historycznej Instytutu Badań Literackich PAN w dn. 18-21 września 2008 r. w Zlotym Potoku.

1 Zob. H. Gombrich, Obraz wizualny, przel. A. Morawińska, w: Symbole i symbolika. Wybrał i wstępem opatrzył M. Głowiński, Czytelnik, Warszawa 1990; por. U. Eco, Nieobecna struktura, przel. A. Weinsberg, P. Bravo, Warszawa 1996. 
transformacjom² ${ }^{2}$ Tym tropem ida kognitywiści, rozgraniczając percepcję, konceptualizację i symbolizację ${ }^{3}$. Nie ulega zatem wątpliwości, że ikoniczność nie jest zjawiskiem naturalnym i nie zakłada wiernego odwzorowywania rzeczywistości. Stanowi wynik skomplikowanych procesów neurofizjologicznych (jak percepcja) i operacji intelektualnych, jak konceptualizacja i symbolizacja, które po percepcji następują, mają charakter podmiotowy i są dokonywane w określonym kontekście pragmatycznym. A jeśli tak, to w sztukach ikonicznych stosunek do rzeczywistości może być równie skomplikowany jak w literaturze.

Zwraca przede wszystkim uwagę nadmiar określeń, oznaczających czynności postrzegającego podmiotu: naśladowanie, rejestracja, falsyfikacja, symulacja, imitacja, odtwarzanie, przedstawienie, prezentacja, reprezentacja, uobecnienie ${ }^{4}$. Wszystkie one stanowią przejawy referencji, ale nie są synonimami. Uważam, że pojęcie referencji obejmuje trzy różne sposoby potraktowania rzeczywistości, które często są utożsamiane, a które warto rozgraniczyć: 1) symulację, 2) reprezentację i 3) transformację.

1. Symulacja dąży do efektu realności, do tworzenia takiej iluzji przedmiotu, która, jak mówił Jean Baudrillard, podważa opozycję fikcji i prawdy ${ }^{5}$. Efektem takich działań byłby falsyfikat, podróbka, dublet identyczny z pierwowzorem, wreszcie - hologram. Problem symulacji to problem założonej identyczności ze wzorcem. Nabiera on coraz większej aktualności w dobie rozwoju nowych technologii, które pozwalają na doskonałe wykorzystywanie złudzeń zmyslowych i tworzenie symulakrów sztucznych kreacji, nie mających odpowiedników w rzeczywistości. Ten problem szczególnie dotyczy filmu, ponieważ technika cyfrowa pozwala dowolnie przekształcać materiał kręcony na żywo, a także generować nowy obraz, z pominięciem rejestracji.

2. Reprezentacja jest, moim zdaniem, niesłusznie utożsamiana $\mathrm{z}$ referencją ${ }^{6}$ W przeciwieństwie do symulacji nie dąży do identyczności

2 Zob. U. Eco, La Production des signes, przel. M. Bouzaher, Paris 1992. O poglądach Eco pisałam szerzej w książce Literatura $i$ semiotyka, Wyd. Naukowe PWN, Warszawa 2001.

${ }^{3}$ Zob. E. Tabakowska, Ikoniczność: podobieństwo i „tertium comparationis", „Przestrzenie Teorii" 2003, nr 2.

4 Por. Z. Mitosek, Między udawaniem a referencjq, w: Sporne $i$ bezsporne problemy wspótczesnej wiedzy o literaturze, pod red. W. Boleckiego i R. Nycza, Wyd. IBL, Warszawa 2002.

5 Zob. J. Baudrillard, Symulakry $i$ symulacja, przel. S. Królak, Wyd. sic!, Warszawa 2005.

${ }^{6}$ Szeroko rozumie ją M.P. Markowski (zob. M.P. Markowski, O reprezentacji, w: Kulturowa teoria literatury. Gtówne pojęcia i problemy, red. M.P. Markowski, R. Nycz, Universitas, Kraków 2006). 
z pierwowzorem, nie likwiduje opozycji prawdy i fałszu7. Zakłada gre iluzji i deziluzji, której celem jest jedynie sygnowanie przedmiotu. Może mniej lub bardziej „odstawać" od wzorca, pomijać cechy jednostkowe, operować uogólnieniem i uproszczeniem, jednym słowem, oferuje nie „rzeczywistość samą”, ale model rzeczywistości. Jest wynikiem procesu konceptualizacji i ma charakter podmiotowy ${ }^{8}$. Reprezentacja otwiera wiele problemów, dotyczących aspektu podmiotowego i przedmiotowego. Podmiotowy charakter rzeczywistości przedstawionej wynika ze sposobu postrzegania świata, percepcji zjawisk, punktu widzenia podmiotu, selekcji i wyboru cech, motywacji pragmatycznej. Natomiast przedmiotowy charakter przedstawień ewokuje problematykę naśladowania rzeczywistości, podobieństwa do wzorca, konwencji przedstawieniowych, efektu prawdziwości i chwytów deziluzyjnych w sposobach przedstawienia, jednym słowem, stylizację na rzeczywistość zewnętrzną.

3. Transformacja wykracza poza stylizację, jej celem nie jest gra iluzji i deziluzji, jak w wypadku stylizacji, ale uchylanie referencji i przekształcanie bytów - aż do nadawania przedmiotom innego charakteru ontologicznego. Nie mamy więc do czynienia z reprezentacją rzeczywistości, ale z jej unieważnieniem, znikaniem i przemianą w inny byt, np. w rzeczywistość surrealną lub w grę form abstrakcyjnych. Przykładem mogą być: seria Drzew Mondriana czy studia rysunkowe Picassa na temat corridy: z rysunku „imitującego rzeczywistość”, poprzez wiele zabiegów upraszczających i syntetyzujących przedstawienie, powstaje abstrakcja, splot linii, które przestają cokolwiek znaczyć. Ale zawsze punktem wyjścia jest rzeczywistość i odbiorca ma okazję obserwować proces transformacji. Jeśli odwołać się do literatury, to mieściłaby się tu problematyka tzw. realizmu magicznego (Garcia Marquez, Ernst Jünger). Transformacja nasuwa wiele pytań. W jaki sposób uchylona zostaje referencja? W jakim celu? Jaka jest postawa odbiorcy wobec kreacji?

Każda z trzech wyodrębnionych postaw zakłada inny stosunek wobec rzeczywistości. Symulacja imituje rzeczywistość, reprezentacja stylizuje, transformacja przekształca. Granice są tu nieostre, ale wyznaczają dwa bieguny skrajne, między którymi mieści się zjawisko referencji: jeden stanowi symulacja, która dąży do tożsamości ze wzorcem, drugi transformacja, która na oczach odbiorcy przekształca wzorzec $\mathrm{w}$ inny byt. Między nimi rozciąga się obszar stylizacji, mniej lub bardziej zaznaczającej działania i dystans podmiotu wobec rzeczywistości. Natomiast

7 Różnicę między symulacją a reprezentacją podkreślał J. Baudrillard, op. cit., s. $11-12$.

8 Zob. na ten temat: Z. Mitosek, op. cit., s. 241-244. E. Tabakowska mówi o elemencie subiektywnym, związanym z postawą obserwatora (konceptualizatora), zob. E. Tabakowska, op. cit., s. 106, 114-116.

11 Ikoniczność i ucieczka od referencji 
wszystkie razem pozwalają mówić o referencji jako o zjawisku skomplikowanym i stopniowalnym: od maksymalnej „wierności” wobec wzorca (symulacja) do całkowitego przekształcenia (transformacja)9.

Wyszczególnione tu postawy podmiotu umożliwiają wielość relacji przedmiotowych, zależnych od użytego medium: tworzywa i techniki artystycznej poszczególnych sztuk, które w różny sposób budują status ontologiczny przedmiotów przedstawionych, sugerują ich samodzielność bytową bądź niesamodzielność albo też zmieniają przedmiot w znak kulturowy. Działania podmiotu nigdy nie są obojętne aksjologicznie, a użyte medium (jak obraz czy język) może być źródłem dalszych komplikacji w przedstawianiu świata. Tę właśnie problematykę - stosunek do referencji i wynikające stąd konsekwencje w sferze przedmiotowej - chciałabym prześledzić na wybranych animacjach Zbigniewa Rybczyńskiego.

\section{Wobec problemu referencji}

Mogłoby się wydawać, że film - jak żadna inna sztuka wizualna jest predysponowany do symulacji rzeczywistości. Takie były przecież jego początki: bracia Lumière kręcili reportaże, które dostarczały silnych wrażeń. Widzowie filmu Przyjazd pociagu na stację $w$ La Ciotat (1895, reż. Louis Lumière) uciekali przed wjeżdżającą na ekran lokomotywą. A i dziś takie same przeżycia oferuje kino trójwymiarowe. Można się nagle znaleźć na dnie oceanu lub uczestniczyć w wyprawie kosmicznej. Nowoczesna technologia zostaje wykorzystana do tworzenia coraz doskonalszych złudzeń zmysłowych i stara się przenieść odbiorcę w nieistniejącą realnie przestrzeń. Czy przyszłością kina jest likwidacja fikcyjnego charakteru filmowych przedstawień? Tworzenie symulakrów, którym w rzeczywistości nic nie odpowiada? Niekoniecznie.

W przeciwnym kierunku zmierzał film awangardowy: dążył do transformacji rzeczywistości i podkreślał sztuczność kreacji. Myślę o Psie andaluzyjskim Buñuela (wg scenariusza Salvadora Dalego, 1928), który poprzez szokujący detal i surrealistyczny montaż tworzył rzeczywistość absurdalną. Doświadczenia surrealistów wykorzystywały także polskie filmy awangardowe $\mathrm{z}$ lat 30. (Przygody cztowieka poczciwego Themerso-

${ }_{9}$ Propozycja niniejsza, oparta na stosunku podmiotu do rzeczywistości, różni się od typologii M.P. Markowskiego, opartej na kryterium podmiotowo-przedmiotowym. M.P. Markowski ( $O$ reprezentacji, op. cit., s. 318-330) wyszczególnił aż cztery „ideologie" (modele, strategie, wizje) reprezentacji: epistemologiczną, ontologiczną, apofatyczną i estetyczną. 
nów, OR - obliczenia rytmiczne Jalu Kurka)10. Ciekawie na tym tle rysują się eksperymenty artystów fluxusu, których poszukiwania w latach 60. manifestowały "odrealnienie" rzeczywistości poprzez zbliżenie fragmentu twarzy czy części ciała (Yoko Ono filmowała np. zamierający na wargach uśmiech, mrugnięcie okiem czy poruszające się pośladki)11. Codzienna rzeczywistość podlegała w ten sposób szokującej transformacji.

Jaką drogą poszedł Zbigniew Rybczyński (ur. 1949), zdobywca filmowego Oscara (1983)? Przede wszystkim uznał, że w filmie pełnometrażowym nie ma już nic do zrobienia i wybrał animację ${ }^{12}$, która daje twórcy całkowitą swobodę i nie uzależnia go od zespołu. Zdecydowanie opowiadał się przeciwko referencji. W rozmowie przeprowadzonej przez Marię Kornatowską (Nowy Jork, 1987) mówił:

Gdzie jest powiedziane, że kino ma być realistyczne? To absurd. Prawda, że kino wspólczesne upodobało sobie realizm. Widać to bardzo wyraźnie zwłaszcza w filmie amerykańskim. Realizm oznacza naśladowanie rzeczywistości. Imitację. Imituje się uczucia, stosunki między ludźmi, stosunki seksualne. Powstaje uproszczony, schematyczny obraz rzeczywistości. To w istocie swoista odmiana porno! Voyeuryzm! Mania podglądania! Ucieczka od rzeczywistości przy zachowaniu pozorów prawdy. Uważam, że imitowanie rzeczywistości nie ma sensu. Jest symptomem życia ułatwionego i w ostatecznym efekcie ogłupia i oszukuje publiczność. Kino nie powinno być realistyczne. Musi być kreacyjne |podkr. moje - S.W.|' ${ }^{13}$.

\section{A nieco później w rozmowie z Tadeuszem Sobolewskim (1990):}

Imitacja nie jest żadną drogą. Ekspresja - wyrażanie samego siebie - nie ma sensu. Cóż takiego można wyrazić? Jedyne nad czym warto pracować, to odkrywanie zasad, w nauce, w sztuce, we wszystkim ${ }^{14}$.

Zafascynowany nową technologią i jej możliwościami, nazywany papieżem wideo, Rybczyński zdecydowanie odrzuca imitację, chociaż mate-

10 Zob. M. Giży cki, „Polski film - dobry!”. Kino w kregach artystycznych dwudziestolecia, w: Wyprawa $w$ dwudziestolecie, pod red. K. Nowakowskiej-Sito, Muzeum Narodowe w Warszawie, Warszawa 2008.

$"$ Zob. M. Giżycki, Anegdotyczna historia fluxfilmu (Maciunas, Yoko Ono i inni), „Kwartalnik Filmowy” 1995, nr 11.

12 Rozumie ją zresztą bardzo szeroko jako każdy film, który nie jest rejestrowany w standardzie 24 klatek na sekundę.

${ }^{13}$ M. Kornatowska, Rozmowa $w$ Nowym Jorku, w: Zbigniew Rybczyński, podróżnik do krainy niemożliwości. Wokót twórczości Zbigniewa Rybczyńskiego, pod red. Z. Benedyktowicza, Instytut Sztuki PAN, Komitet Kinematografii [bez daty wydania], s. 40.

14 T. Sobolewski, Fantazja na żywo (rozmowa ze Zbigniewem Rybczyńskim), w: Zbigniew Rybczyński, podróżnik do krainy niemożliwości..., s. 107; por. drugą rozınowę opracowaną przez T. Sobolewskiego, Uwolnić się od rzeczywistości... 
rią jego animacji jest wcześniej zarejestrowana rzeczywistość15. Studiuje problemy widzenia i opracowuje nowe techniki tworzenia obrazu. Efektem jego badań i eksperymentów są trzy opatentowane w USA wynalazki (1997, 2000, 2002), a sumą przemyśleń i artystycznym credo - Traktat o obrazie ${ }^{16}$.

W Traktacie... Rybczyński wyróżnia trzy kategorie obrazów: 1) informacyjne (tj. rejestrowane przez wzrok), 2) mentalne (powstające w mózgu, generowane przez sny i wyobraźnię) oraz 3) symboliczne, będące efektem całego procesu widzenia (rejestracji i wyobraźni), utrwalonym na papierze czy ekranie. Uważa, że współcześnie obraz symboliczny traktowany jest wyłącznie jako imitacja obrazu informacyjnego i pragnie to zmienić, ograniczyć rejestrację na rzecz wyobraźni, za pomocą elektroniczno-komputerowych technik. Postuluje tworzenie obrazów, które imitują obrazy mentalne, nie lekceważąc rejestracji rzeczywistości. Jest w swych poglądach konsekwentny. Można zatem postawić pytanie, jak w jego filmach („obrazach symbolicznych" utrwalonych na ekranie) wygląda problem referencji? Zanalizujmy to na takich przykładach, jak Święto (1976), Lokomotywa (1976)17, Tango (1980), Czwarty wymiar (1988) i Orkiestra (1990).

\section{Święto (1976), czyli rzeczywistość zdeformowana}

Kolega Rybczyńskiego z Łódzkiej Filmówki, Andrzej Barański, który z nim nakręcił trzy filmy ${ }^{18}$, krytycznie spojrzal na cytowane wyżej wypowiedzi:

Bo przecież w pewnym momencie on również poszedł w pokazywanie rzeczywistości. Na przykład to jego Swięto, to jest jakby taką satyrą na te niedzielne obrzędy Polaków, świąteczny obrządek ${ }^{19}$.

15 Podkreślał to R. Ciarka (zob. R. Ciarka, Zbigniew Rybczyński-pomiędzy awangardq $i$ syntezq, w: Zbigniew Rybczyński, podróżnik do krainy niemożliwości...).

${ }_{16}$ Z. Rybczyński, Traktat o obrazie / A Treatise on the Visual Image, Art Stations Foundation, Poznań 2009.

17 Swięto i Lokomotywa rzadko były omawiane. Powstały po głośnych filmach Rybczyńskiego: Zupie (1974), Nowej ksiażce (1975) oraz Oj, nie mogę się zatrzymać (1975) i, według R.W. Kluszczyńskiego, nie wprowadzają nowych elementów do poetyki artysty (zob. R.W. Kluszczyński, Zbigniew Rybczyński albo kino jako wideo, w: R.W. Kluszczyński, Film - wideo - multimedia. Sztuka ruchomego obrazu w erze elektronicznej, Instytut Kultury, Warszawa 1999, s. 167).

${ }_{18}^{8}$ Rybczyński był operatorem trzech filmów Barańskiego: Krętych ścieżek, Dnia pracy (oba filmy z 1971 r.) i Podania (1972).

19 Nasze „Kręte ściezki”. O Zbigniewie Rybczyńskim opowiada Andrzej Barański, w: Zbigniew Rybczyński, podróżnik do krainy niemożliwości.., s. 153. 
Nie sposób się z Barańskim nie zgodzić: Święto jest 10-minutową satyrą obyczajową. Można powiedzieć, że jest to wyjątkowy utwór Rybczyńskiego. Pokazuje małomiasteczkową polską prowincję i jej kontrasty: $\mathrm{z}$ jednej strony brak kanalizacji (woda z pompy, wygódka z serduszkiem), kury na podwórzu, $\mathrm{z}$ drugiej - dom murowany, a w domu telewizor, a jakże, i auto w garażu, które się od święta myje. Ale znacznie ciekawsze jest, jak Rybczyński tę polską rzeczywistość pokazuje, a ściślej - jak ją deformuje i wyśmiewa. Robi to wszystko środkami filmowymi. Eliminuje słowo, rezygnuje z dialogów i deformuje przedstawienia poprzez kolor i ruch. Jaskrawy kolor odrealnia ludzi, zwierzęta i rzeczy. Na filmie pies jest czerwony, kot - zielony. Ludzie, ukazywani w tonacji jaskrawo żółtej i czerwonej (jak kochająca się w krzakach para), poprzez kolor zostają odindywidualizowani. Widziani nieostro, zamieniają się $\mathrm{w}$ barwne plamy (zupełnie inaczej niż we wcześniejszej Zupie (1974), gdzie ostre, zdecydowane kolory podkreślały kontury postaci). Tak zostali sfilmowani goście witani przed domem, siedzący przy świątecznym stole i później żegnani przez domowników. Sekwencje z gośćmi (pocałunki, toasty i bruderszafty) zostają wyszydzone poprzez kilkakrotne powtarzanie tych samych gestów, mechanizację i przyspieszenie ruchów. Podczas uroczystego posiłku piszczy kurczę i warczy pies - i te konkretne dźwięki, jak w filmie niemym, pojawiają się na ekranie, zastępując banalne słowa, które padają w takich okazjach.

W Święcie Rybczyński nie imitował, ale środkami filmowymi deformował rzeczywistość i szydził z niej. Stworzył groteskę poprzez odindywidualizowanie postaci, eliminację słowa i manipulacje techniczne (kolor, mechanizację ruchu, przyspieszenie biegu taśmy).

\section{Lokomotywa (1976) bez lokomotywy, czyli rzeczywistość zredukowana}

W ekranizacji Lokomotywy Tuwima (1976) tytułowa bohaterka została pozbawiona wizualnego desygnatu. Jak może być Lokomotywa bez lokomotywy? Rybczyński pokazał, że może.

Wiersz Tuwima stanowi doskonały przykład ikoniczności tekstu literackiego. Przede wszystkim ikoniczny jest język, bogaty w akustyczne walory, pełen powtórzeń, aliteracji i onomatopei. Natomiast rzeczywistość przedstawiona to świat przeróżnych przedmiotów, ludzi i zwierząt (także egzotycznych ${ }^{20}$ ), których autor nie opisuje, podkreśla tylko to, co

20 Opozycja egzotyki i swojskości dała W. Tomasikowi okazję do uwag o dyskursie kolonialnym w Lokomotywie (zob. W. Tomasik, Ikona nowoczesności. Kolej w literaturze polskiej, Wrocław 2007, s. 226). 
je wszystkie lączy: ciężar i duży gabaryt. Taki tekst aż się prosi o dźwiękową i wizualną konkretyzację. Tymczasem nic z tego. Mamy tu do czynienia nie $\mathrm{z}$ konkretyzacją przedstawien, ale $\mathrm{z}$ przekładem intersemiotycznym. Rybczyński zneutralizował ikoniczność języka poprzez śpiew, który zastąpił tradycyjną recytację, a przede wszystkim okrutnie potraktował starą, parową lokomotywę, która w ogóle nie została pokazana. Widzimy tylko (trzy razy) ujęcie kół i tory (skonkretyzowane jest za to jedyne w tekście Tuwima porównanie: ,jak żółw"). Zamiast parowozu na ekranie pojawiają się parujący garnek i czajnik. Desygnatu nie ma, a jego cechy zostały dowcipnie przełożone na czynności obwieszonego bagażem podróżnego, który liże loda i zrzuca wierzchnią odzież (bo mu gorąco), gwiżdże, kuje żelazo, stuka młotkiem, obroty kół rozpędzonej maszyny ilustruje, kręcąc łyżką w misce, szarpie się ze swoim sobowtórem itp. Ikonizacja przedmiotowa została zastąpiona przez ikonizacje czynnościową. Taka wizualizacja Tuwimowej Lokomotywy jest polemiczna zarówno wobec wszelkich ilustracji książkowych tego tekstu, traktowanego jako dziecięca encyklopedia, jak również wobec klasyki filmowej. Już w 1922 r. Koto udręki Abla Gance'a pokazywało pęd pociągu poprzez mnożenie krótkich ujęć i cięty montaż ${ }^{21}$. Rybczyński z tego wszystkiego zrezygnował. A jak przedstawił transportowane pociągiem przedmioty? Ukazywał nie ilość, ale pojedyncze egzemplarze, z reguły potraktowane pragmatycznie. Widzimy więc krowę, którą się doi i konia, którego człowiek dosiada. A jeśli już mamy na ekranie klasyczną animację, to przedmiot musi być w ruchu: stoły kroczą, a niegroźna, narysowana armata wygina miękko lufę i wypluwa koło siebie kulę. Przedmiot sygnalizowany bywa również poprzez czytelną metonimię (np. skacząca małpa zastępuje transportowane banany). Co najciekawsze, pęd lokomotywy ukazany został z punktu widzenia pasażera poprzez migające budynki i wywracający się do góry krajobraz. Podróżny zresztą zostaje przedstawiony $\mathrm{w}$ surrealnej sytuacji: $\mathrm{w}$ końcowej części utworu stoi na szczycie drabiny 22 ustawionej na torach albo fruwa na koniu nad wodą.

Lokomotywa pokazuje, że nawet najbardziej referencjalny tekst da się wizualizować niereferencjalnie i to prostymi środkami poprzez metaforę czynnościową i metonimię, które pseudonimują rzeczywistość. Ponadto referencję można całkowicie uchylić, kreując sytuacje surrealne, możliwe do realizacji w filmie. I tą wlaśnie drogą idzie Tango.

21 Według J. Płażewskiego, „impresjonistyczny montaż polifoniczny” w Kole udręki składa się z bardzo krótkich ujęć pędzącego pociągu, kół, wnętrza parowozu, widoku szybkościomierza i dymiącego komina, co wywoluje wrażenie pędu (zob. J. Płażewski, Język filmu, Warszawa 1982 , s. 145,161 ).

22 Być może, pomysł drabiny i śpiewu zamiast recytacji nasunęła Rybczyńskiemu głośna inscenizacja Kordiana Adama Hanuszkiewicza (1970). 


\section{Tango (1980), czyli rzeczywistość surrealna}

Tango, nagrodzone Oscarem w 1983 r. za najlepszy krótkometrażowy film animowany, trwa niecałe 8 minut i przedstawia czynności 26 osób23, wchodzących i wychodzących z pokoju przy akompaniamencie muzyki tanecznej. Czynności te są zwykłe, codzienne i powtarzane po wielokroć (chłopiec wchodzi oknem, matka karmi niemowlę, złodziej kradnie paczkę, dziewczynka robi lekcje, kobieta niesie zupę itp.). Nie byłoby $w$ nich nic niezwykłego, gdyby nie dwa zabiegi reżysera: po pierwsze precyzyjna kompozycja ruchu postaci (do pokoju wchodzi coraz więcej osób, w końcu wszystkie znajdują się w nim jednocześnie, a później pokój się sukcesywnie wyludnia) i po drugie chociaż w pokoju robi się tłok, postacie zachowują się tak, jakby nikogo obok nich nie było. Wykonują swoje czynności nienaturalnie, są nieme, głuche i ślepe na to, co dzieje się dookoła. W ten sposób, poprzez eliminację wzajemnych związków i zależności, zostaje uchylona referencja i tworzy się przestrzeń absurdalna. Można więc mówić o obsesji przestrzeni, całkowicie wypreparowanej z czasu, ponieważ czynności postaci i tło akcji są stale takie same. Nie istnieją w filmie żadne znaki upływu czasu, króluje bezczas $^{24}$. Tango nasuwało krytykom dwa pytania: jak to zostało zrobione? I co to wszystko znaczy?

Pytanie o technikę filmowego przedstawienia nie było bezzasadne i Rybczyński chętnie mówił, że wyprzedził wideo i symulacje komputerowe. Każdą z osób filmował osobno, każda musiała poruszać się precyzyjnie po swoim torze, wyrysowanym na podłodze. Później odpowiednio preparował taśmę i nakładał na siebie kolejne epizody, żeby uzyskać efekt zagęszczenia powierzchni, a jednocześnie całkowitej izolacji bohaterów ${ }^{25}$. Tango ma więc budowę warstwową w sensie jak najbardziej dosłownym.

Gorzej z odpowiedzią na drugie pytanie. W wywiadzie dla „Andy Warhol's Interview Magazine” spytano: „Czy teraz, gdy wygrał pan Oscara, może nam pan powiedzieć, co oznacza Tango", Rybczyński odpowiedział: „Absolutnie nic"26.

23 Jest to maksymalna liczba osób, zanotowana w scenopisie Rybczyńskiego, który uwzględnił również „niemowlę karmione przez matkę” oraz „raczkujące niemowlę”.

${ }^{24}$ Co nie znaczy, że Rybczyński był niewrażliwy na problematykę czasu. Eksperymenty z czasem przeprowadził w Nowej ksiqżce (1975), ukazującej wydarzenia symultanicznie na podzielonym na 9 części ekranie, czy też w Imagine (1986) i w II epizodzie Orkiestry (1990), gdzie zostal pokazany proces dorastania i starzenia się bohaterów.

25 Dokładnie opisał tę technikę D. Szczechura w artykule "Tango" czyli nowe spojrzenie na kino, w: Zbigniew Rybczyński, podróżnik do krainy niemożliwości...

${ }^{26}$ Zob. M. Matousek, Wywiad ze Zbigniewem Rybczyńskim dla „Andy Warhol's Interview Magazine”, w: Zbigniew Rybczyński, podróżnik do krainy niemożliwości..., s. 85. 
Jednak sprawa nie jest taka prosta. Tango można czytać co najmniej na trzy sposoby: 1) referencjalnie - to znaczy mówić o demokratyzacji społeczeństwa i o ciasnocie mieszkaniowej w Polsce, bo takie interpretacje również istnieją 27,2$)$ „filmowo", interesując się sztuczkami technicznymi i ewentualną niekonsekwencją autora oraz 3) semiotycznie.

Uchylenie referencji (a sygnały są tu czytelne) powoduje, że odbiorca szuka znaczeń konotowanych. Interpretuje ukazywane czynności jako znaki i - w myśl cytowanych wyżej słów Rybczyńskiego - stara się odkryć zasadę, która nimi kieruje. Znaki dają się ułożyć w dwie opozycje: narodziny/śmierć (jedno z pierwszych ujęć pokazuje karmiącą matkę, a końcowe - umierającą staruszkę) oraz natura/kultura (postacie wykonują szereg czynności fizjologicznych (karmienie piersią, jedzenie, spółkowanie), a jednocześnie obok „biologii” na ekranie obserwujemy zajęcia intelektualne: dziewczynka odrabia lekcje, pan czyta gazetę).

Surrealna przestrzeń skłania także do interpretacji egzystencjalnych: samotności w tłumie, alienacji jednostki, codziennego absurdu, w jakim tkwi. Niewykluczone są także dociekania psychoanalityczne (szukanie mechanizmów podświadomych). Można też zastanawiać się nad muzycznym akompaniamentem i tytułem. Dlaczego właśnie tłem muzycznym stało się tango? Czy dlatego, że tango straciło swój charakter narodowy, spopularyzowało się i umiędzynarodowiło? W filmie chyba podkreśla aspekt uniwersalny (a w każdym razie nienarodowy). Jeśli te wszystkie odczytania są wbrew intencjom autora, to, niestety, są przez niego sprowokowane poprzez uchylenie referencji.

\section{Czwarty wymiar (1988), czyli rzeczywistość w procesie transformacji}

Czwarty wymiar powstał w USA $\mathrm{w}$ technice wideo, chociaż, jak twierdził Barański, nie tylko pomysł, ale scenopis filmu zrobiony był jeszcze $\mathrm{w}$ Łodzi ${ }^{28}$. Jest to 20-minutowa etiuda (z muzyką Michała Urbaniaka) o tęsknocie, pożądaniu i miłosnym zespoleniu dwojga ludzi. Uczucia miłosne zostały przełożone na obraz - wyrażone poprzez wizualną transformację postaci, które nie ruszając się $\mathrm{z}$ miejsca, pozostają nieustannie w płynnym ruchu wokół własnej osi lub po elipsie. Wydłużają się, skręcają na kształt wstęgi Möbiusa, oplatając wzajemnie swoje sylwetki. Ryszard W. Kluszczyński pisał:

27 Zob. M. Giżycki, Wizja i kalkulacja, w: Zbigniew Rybczyński, podróżnik do krainy niemożliwości..., s. 29 oraz Ch. Solom on, "Tango” - polski taniec alienacji, w: Zbigniew Rybczyński, podróżnik do krainy niemożliwości..., s. 37.

${ }^{28}$ Zob. A. Barański, op. cit., s. 153. 


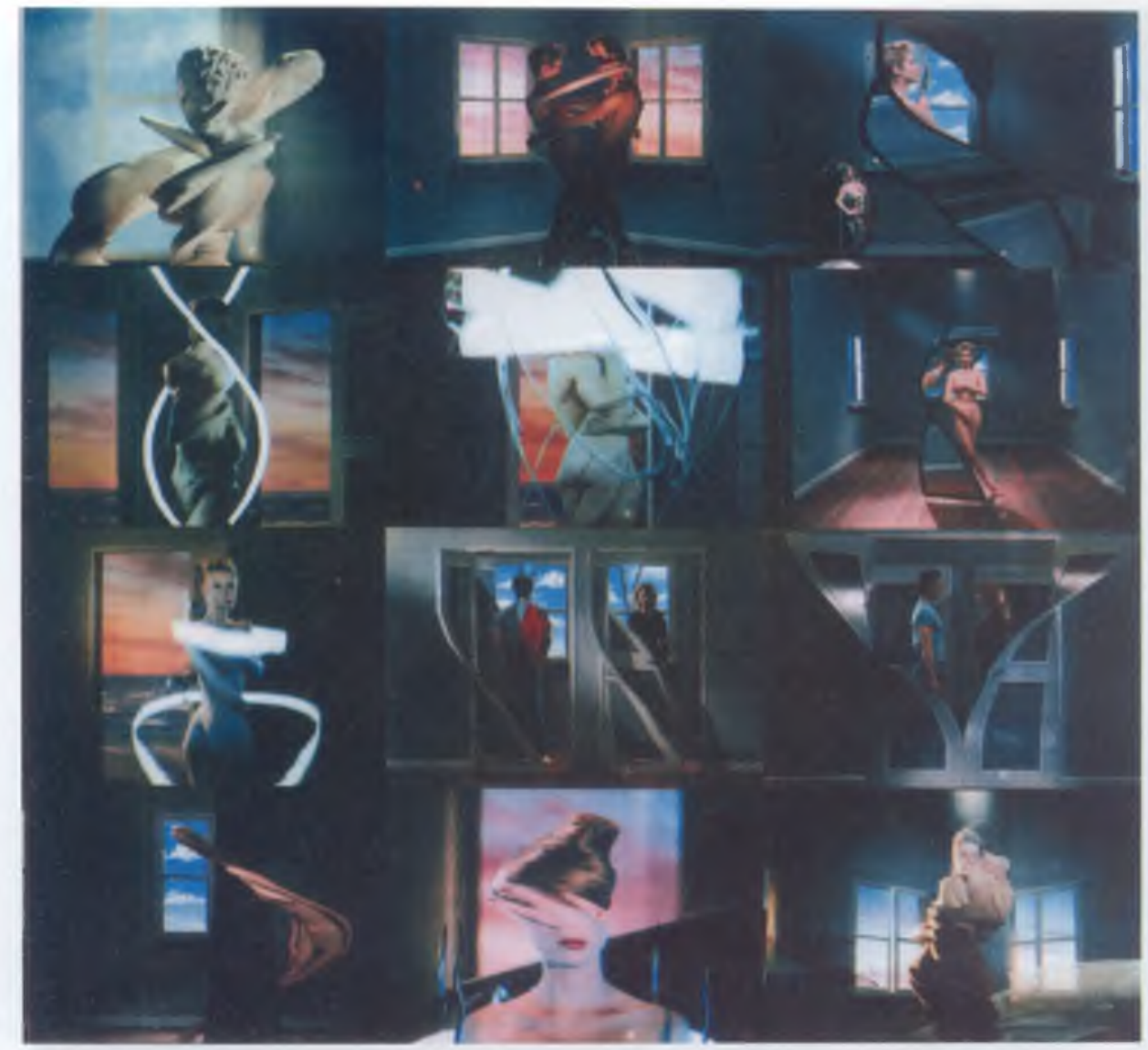

Czwarty wymiar: 12 ujęć pokazujących ruch oraz deformację postaci i przedmiotów (pierwsze górne ujęcie z lewej przedstawia dwie główki antyczne obracające się wokół siebie), repr. za: Zbigniew Rybczyński, Traktat o obrazie, Art Stations Foundation 


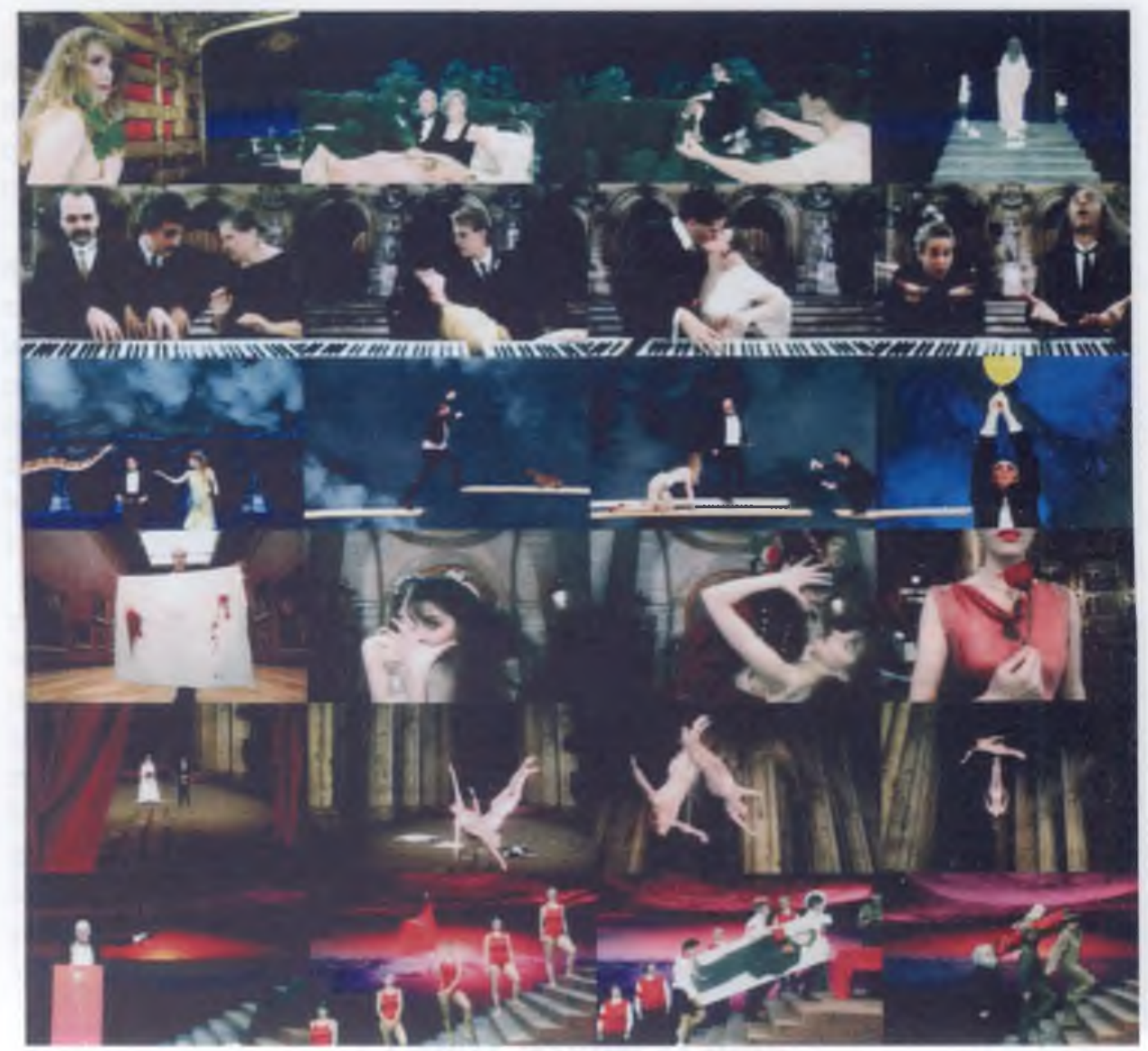

Orkiestra: 24 ujęcia (po $4 \mathrm{z}$ każdego uszeregowanego poziomo epizodu). Od góry kolejno: I epizod (Mozart, pierwsze ujęcie z lewej pokazuje fragment wnętrza Opery paryskiej); II epizod (Chopin, przed gmachem Opery); III epizod (Albinioni); IV epizod (Rossini, pierwsze ujęcie w Sali Louvru, pozostałe w Operze); V epizod (Schubert, we wnętrzu katedry w Chartre); ostatni u dołu VI epizod (Ravel), repr. za: Zbigniew Rybczyński, Traktat o obrazie, Art Stations Foundation 
Materia w Czwartym wymiarze jest skrajnie plastyczna. Nic nie zachowuje stałości kształtów. Nieustanne transformacje i zmiennośc - to jedyna trwała własność tego świata. Skomponowana przez Michała Urbaniaka muzyka znakomicie towarzyszy swoją płynną zmiennością przeobrażeniom wizualnym ${ }^{29}$.

W spektaklu biorą udział nieliczne rekwizyty, które podlegają tym samym prawom: dwie główki antyczne obracające się wokół siebie czy kieliszek wina miękko oplatający butelkę. Ascetyczna przestrzeń nie jest więc całkiem pusta. Towarzyszą jej znaki kulturowe: klasycystyczna rzeźba, Mona Liza (która zwija się w klepsydrę), czerwone jabłka, ogień, szachownica, a na końcu zbliżenie muszli jako znak ostatecznego spełnienia. Zaczyna i kończy film ta sama sekwencja: płonąca świeca i zapisana karta papieru, co można interpretować jako antynomię uczuć i intelektu, przemijania emocji i trwałości tego, co zapisane. Arsenał kultury - tak skomentował Paul Virilio:

Ja wcale nie upatruję w tym czwartego wymiaru. Dla mnie jest to przestrzeń bardzo przestarzala, w istocie bardzo leibnizowska, zakorzeniona w pamięci od XVII-XVIII stulecia. Ten film The Fourth Dimension rekapituluje cala wiedze. Stanowi on w gruncie rzeczy Muzeum Sztuki Zachodniej. Czwarty wymiar staje się w końcu wymiarem historii. Tym, co zaszło od Renesansu aż po dzień dzisiejszy, po Magritte'a [podkr. moje - S.W.] ${ }^{30}$.

Czwarty wymiar pokazuje plastykę ludzkiego ciała i w sposób malarski wizualizuje sytuację, zdawałoby się, nieprzedstawialną. Jednakże Rybczyński na wizualizacji nie poprzestał, wprowadził do filmu autokomentarz, sugerowany poprzez czytelne dla odbiorcy symbole kulturowe.

\section{Orkiestra (1990), czyli rzeczywistość zamieniona w znaki}

Późniejsza o 10 lat od Tanga, a dwa lata od Czwartego wymiaru Orkiestra kręcona była w USA techniką wideo (w systemie High Definition). Trwa 50 min i składa się z 6 różnych epizodów, których zdawałoby się nic nie łączy. Tymczasem wszystkie one rozgrywają się w przestrzeni kulturowej, łatwej do identyfikacji dla Europejczyka, a większość z nich

${ }^{29}$ R. W. Kluszczyński, op. cit., s. 173.

${ }^{30}$ P. Virilio, Fenomen Rybczyńskiego, w: Zbigniew Rybczyński, podróżnik do krainy niemoźliwości..., s. 48. Por. M. Baranowska, Realizm symboliczny, w: Zbigniew Rybczyński, podróżnik do krainy niemożliwości..., s. 191. Dokładniej o inspiracjach grafiką M.C. Eschera oraz obrazami S. Dalego i R. Magritte'a w Czwartym wymiarze pisze Katarzyna Kostrzewska (zob. K. Kostrzewska, Inspiracje malarskie w kinie Rybczyńskiego, „Kwartalnik Filmowy” nr 19-20, 1997-1998, s. 289-290. 
we wnętrzu Opery paryskiej (albo koło niej). I tak epizod I, któremu towarzyszy muzyka Mozarta, w klasycystycznym parku; epizod II - „chopinowski" przed gmachem Opery, epizod III (z muzyką Albinioniego) ponad Operą, na zawieszonych w przestrzeni kładkach; epizod IV (Rossini) w sali Louvru i w foyé Opery; epizod V - we wnętrzu katedry w Chartres. Wyjątek stanowi epizod VI (Ravel), który rozgrywa się w sztucznie skonstruowanej przestrzeni studia. I co ciekawe, przestrzeń architektoniczna nie jest symulowana, jest zarejestrowana na filmie (Opera i Louvre były kręcone w Paryżu, katedra w Chartres). W tę realnie istniejącą kulturową przestrzeń wkomponowane zostały filmowane w studio epizody. Ale uchyla referencję rama teatralna: wszystko, co widzimy, dzieje się na scenie wytwornej Opery paryskiej. Rama nie tylko zaczyna i kończy całość, ale stanowi przerywnik pomiędzy epizodami, przypomina, że mamy do czynienia z fikcją, zaś na końcu, jak w teatrze, aktorzy wychodzą przed kurtynę i kłaniają się publiczności!

Kwestionują referencję również surrealne sytuacje, wokół których zbudowane są poszczególne epizody, np. karawan nad brzegiem morza (w pierwszym ujęciu), olbrzymia klawiatura przed gmachem Opery, na którą spadają z nieba prezenty (w epizodzie II), wędrówka po zawieszonych w przestrzeni kładkach (epizod III), multiplikacja postaci w tańcu (epizod IV), wzlot nowożeńców pod strop gotyckiej katedry (epizod V) i wiele innych.

Rzeczywistość zostaje unieważniona, co otrzymujemy w zamian? powszechnie czytelne znaki kulturowe. Anna Sobolewska pisze:

Rybczyński pokazuje, że przestrzeń człowieka jest zawsze przestrzenią symboliczną. Pojawiają się kluczowe motywy: jabłko, ogień, chleb i wino, wąż. Czasem jest to przestrzeń sakralna, jak w sekwencji z Ave Maria Schuberta, której tlem jest katedra w Chartres. W ostatniej sekwencji - Bolero Ravela - mamy do czynienia z przestrzenią sakralną na opak; jest to sacrum komunistyczne, zdegradowane, fałszywe, beznadziejne. Ale za każdym razem jest to przestrzeń symboliczna. Poza tę przestrzeń czlowiek nie może się przebićc ${ }^{31}$.

\section{I nieco dalej:}

W dziełach Rybczyńskiego wszystkie przedmioty są znakami - nie przyciągają uwagi swoim bytem w sobie, ale odsyłają poza siebie. Są wśród nich symbole dawnych epok i symbole naszej współczesnosci, np. telefon i sedes. Nawet przyroda wydaje się tu artefaktem istniejącym tylko dzięki łasce artysty. Rybczyńskiego cechuje absolutna swoboda posługiwania się symbolem - zamiast jabłka wprowadza od razu całą tacę jabłek, wąż jest tu wielkości boa ${ }^{32}$.

31 A. Sobolewska, Konstrukcja istnienia, w: Zbigniew Rybczyński, podróżnik do krainy niemożliwości..., s. 109.

32 Tamże, s. 112; por. M. Baranowska, op. cit. 
Co ciekawe, każdy z epizodów Orkiestry buduje innego typu rzeczywistość symboliczną:

I epizod (Mozart) - kulturową;

II epizod (Chopin) - narodową;

III epizod (Albinioni) - obyczajową;

epizody IV (Rossini) i V (Schubert) - erotyczną;

VI epizod (Ravel) - polityczną.

Epizod I Mozartowski wręcz przeładowany jest znakami kulturowymi. Krytycy mówili o ogrodzie rozkoszy ziemskich, w którym przebywają zmarli, ożywieni na chwilę przez reżysera (kelnera i sztukmistrza jednocześnie). Możemy tam znaleźć, jak na starych obrazach, wyeksponowane, płynące w powietrzu alegorie poszczególnych zmysłów (kieliszek wina, kwiat, cygaro), topikę życia jako wędrówki (bagaże podróżne), symbole cmentarne i łódź Charona, którą zmarli odpływają w przestworza.

Epizod Chopinowski wprowadza symbole narodowe, elementy powstańczej martyrologii (marsz żałobny Chopina, czarne stroje, okrwawieni, obwiązani szmatami ludzie). Nie znaczy to, że w epizodzie nie ma innych znaków, jak np. przemiana pokoleń (akordy na klawiaturze uderzają najpierw dzieci, później osoby coraz starsze) czy dramatów obyczajowych (uwodzenie i zdrada).

Znaki obyczajowe dominują w epizodzie następnym (III). Mężczyzna idący ostrożnie w takt muzyki Albinioniego na zawieszonych w przestrzeni kładkach mija narkomana robiącego sobie zastrzyk, kochającą się parę, samobójcę. Widzi konflikty i dramaty kończące się upadkiem w przepaść. Pojedyncze miniscenki stają się znakami kondycji współczesnego społeczeństwa. Nie brak tu wizualizacji znanych toposów (np. „wiódł ślepy kulawego").

Epizod IV przedstawia żywiołowy taniec „dam i huzarów”, rozgrywany w takt muzyki Rossiniego w sali Louvru i w foyer Opery paryskiej. Elegancka przestrzeń architektoniczna i surrealistyczne chwyty (np. multiplikacja postaci) stanowią tło znaków orgii seksualnej, która przypieczętowana zostaje tradycyjną topiką: rozsypaną na schodach tacą jabłek i kończącym epizod zbliżeniem orchidei.

Epizod V jest najkrótszy, trwa tylko 5 min. Przedstawia nowożeńców we wnętrzu katedry w Chartres, którzy zrzucają ślubne szaty i przy dźwiękach Ave Maria Schuberta szybują w górę, aż pod strop katedry. Scena jest wizualizacją metafory językowej (obrazuje „wzlot miłosny”, „uniesienie miłosne”), a jej liryczny i podniosły charakter kontrastuje z żywiołowym biologizmem epizodu poprzedniego i z rewolucyjną topiką następnego. 
Ostatni, VI epizod rozgrywany przy dźwiękach Bolera Ravela to utrzymany w czerwonej tonacji marsz po niekończących się schodach, którymi kroczą różne grupy społeczne (robotnicy, robotnice, prostytutki, dzieci, sportowcy itp.). Wszyscy niosą symbole rewolucyjnej Rosji: sierp i młot, popiersia Lenina, czerwone sztandary i chusty, plakaty z rosyjskimi napisami. Na schodach rozgrywają się miniscenki: rewizja osobista, akty terroru, rozmowa telefoniczna. Kończy pochód ostatni akord Bolera i kiczowaty (niestety) znak upadku komunizmu: waląca się w dół trumna ze szkieletem w środku.

Tak różne epizody łączy nie tylko rama teatralna, ale także wspólne motywy: pojawiający się często na ekranie karawan i kobieta-kusicielka ( $\mathrm{z}$ jabłkiem lub wężem).

W ucieczce od referencji Orkiestra stanowi punkt dojścia: zamianę rzeczywistości w znaki. Rybczyński tworzy je na własny użytek, fascynując wyobraźnią i pomysłowością, ale także korzysta z tradycyjnej topiki, funkcjonującej w świadomości europejskiej. Sięga po ikony kulturowe ${ }^{33}$, posługuje się aluzją, wykorzystuje malarstwo i architekturę. Można postawić pytanie o rolę kodu muzycznego, czy i jak wspiera konotacje kulturowe. W tej sytuacji tytuł filmu ${ }^{34}$ staje się wielką metaforą. „Orkiestra” konotuje nie tylko muzykę, ale i grę kulturowymi znakami.

\section{Podsumowanie}

Twórczość Rybczyńskiego pokazuje, że jest on niesłychanie konsekwentny. Chociaż materią jego animacji jest rzeczywistość, nie chce jej symulować ani reprezentować. Poddaje ją transformacji różnymi sposobami, deformuje (Święto) i przekształca (Tango, Czwarty wymiar, Orkiestra). Czy ograniczenie referencji otwiera drogę „obrazom mentalnym”, generowanym przez sny i wyobraźnię? Oczywiście, tak. Tango i Czwarty wymiar to przykłady gry emocji i wyobraźni. Ale na nich się nie kończy. Okazuje się, że „obrazy mentalne” to także - jak pokazuje Orkiestra utrwalone $\mathrm{w}$ świadomości społecznej (a więc konwencjonalne) symbole kulturowe. Uchylenie referencji prowadzi w świat znaków. Poprzez znaki obyczajowe, polityczne, kulturowe, które - od Czwartego wymiaru mnożą się w filmach Rybczyńskiego, wracamy do czasu historycznego,

33 Późniejsze od Orkiestry „amerykańskie” filmy Rybczyńskiego jak Manhattan (1991) i Washington (1991) idą w tym właśnie kierunku.

${ }^{34}$ Współpracownik Rybczyńskiego, Miłosz Benedyktowicz, mówił, że w trakcie realizacji koncepcja filmu uległa zmianie, ale ze względu na producentów nie zmieniono tytułu (zob. Dyskusja w Pracowni Teorii i Historii Filmu Instytutu Sztuki PAN „Co znaczy orkiestra”, w: Zbigniew Rybczyński, podróżnik do krainy niemożliwości..., s. 91). 
polityki, geografii i śródziemnomorskiej tradycji. A sam autor - po przygodach w świecie znaków - tęskni do reprezentacji. Świadczy o tym wymownie jego ostatni film, Kafka (1992), który mimo nazwiska pisarza $\mathrm{w}$ tytule nie jest filmem biograficznym, ale portretem literackim, kreacją z listów, dzienników i wątków powieściowych. „Kafka syntetyczny” zyskał na ekranie walor reprezentatywności, a nie walor autentyku. Jeszcze bardziej wymowne są plany Rybczyńskiego na przyszłość - zamiar zrobienia dokumentu o historii polskich Żydów ${ }^{35}$.

Niniejsze rozważania pozwalają także na sformułowanie refleksji natury ogólnej. Okazuje się, że uchylenie referencji skłania autora do tworzenia znaków i budowania własnego świata, opartego na nowych zasadach. Albo też - do czerpania z istniejącego arsenału topiki kulturowej.

I nawet najdalej posunięta transformacja rzeczywistości w znak nie zrywa $\mathrm{z}$ empirią. Znaki maja charakter podmiotowy, stanowią wizualizacje indywidualnego lub społecznego doświadczenia. W ostatecznym rachunku odsylaja do rzeczywistości, od której nie ma ucieczki ${ }^{36}$.

35 Mówił o tym w Poznaniu na festiwalu Animator 2008 (zob. M. Kaźmierska, Moc wyobraźni, „Gazeta Wyborcza", Poznań 12-13 lipca 2008, s. 6).

${ }^{36}$ Ten wniosek jest polemiczny wobec typologii M.P. Markowskiego, który „reprezentację estetyczną" przedstawia jako autonomiczną sferę, zrywającą z doświadczeniem empirycznym (zob. M.P. Markow ski, O reprezentacji, w: Kulturowa teoria literatury. Gtówne pojęcia i problemy..., s. 326-328). 